\title{
Ishwar Chandra Vidyasagar's Contribution in the Development of Bengali Language and Literature and Its Relevance in Present Context
}

\author{
Roni Ghosh \\ M.Phil Scholar of Dept. of Education. University of Kalyani, West Bengal, India \\ E-Mail: ronighosh22@ rediffmail.com
}

\begin{abstract}
Ishwar Chandra Vidyasagar was a great person and great human being. He is known not only for his contribution in the field of educational and social reformation, but also for his literary works and contribution in the development of modern Bengali language. $\mathrm{He}$ is the pioneer who understood the problem of the then readers in understanding the complicated Bengali language, whose origin was purely Sanskrit. Thus, he took initiatives for simplifying and modernizing this language. Before him there was no such simple, easy and systematic text books for the learners. So, the researcher aims to find out the literary works of Ishwar Chandra, his contributions in the development of modern Bengali language and its present day relevancy in education. To fulfill these aims and objectives the researcher has framed some research questions. This is a Historical and Bibliographical research. Necessary data are collected from the primary and secondary data sources. For the analysis and interpretation of collected data, researcher used documentary analysis method. According to the researcher this research has significance from many aspects. One of them is, it will reveal the contribution of Ishwar Chandra Vidyasagar as the first writer of Bengal in creating the simple and modern Bengali language. But the study is delimited by the researcher from the time period, i.e. only the time between 1820-1891 is considered as the period under study. After collecting necessary data, the researcher has found that, large number of books has been written by Ishwar Chandra and he has memorable contribution in the development of modern Bengali language. One of his popular creations is "Barna Porichay". It is also found that he had done many activities like, writing of text books, grammar books, bio-graphical books and was actively involved in the writings of some magazines. Following the third research question, the research has found that Ishwar Chandra's all activities are not somehow done by him, but those were much planned works. His report regarding the reformation of the educational system of Sanskrit college is considered as the first Educational Plan by the Indians. His works and activities regarding language development and literature support the principles of educational philosophy and psychology even after a long period of three centuries.
\end{abstract}

Keywords: Literary works, Language development, Educational Philosophy, Psychology, Relevance

\section{INTRODUCTION}

"Pandit Ishwar Chandra Vidyasagar", the name very close to the hearts of Bengalis and also the Indians, was none other than the famous writer, educationist, philanthropist, social reformer, humanist, teacher and one of the most intellectuals in the world. He was the glittering star of $19^{\text {th }}$ century. $\mathrm{He}$ is also called 'Sind River of kindnesses' because of his sympathy and pain for the poor and downtrodden people. He had great devotion to his study and was very disciplined and obedience to his mother. He was a multi-talented person, which we can see through his works and activities. Throughout his life he has done so many activities for the betterment of the society, improvement the conditions of women, enrichment of Bengali literature and modernizing Indian education. He was influenced by the outlook and liberal thoughts of the famous Ramkrishna Paramhansa Dev. They both have respects for each other. Amongst the educationists and writers of the $19^{\text {th }}$ and early $20^{\text {th }}$ century like Rabindra Nath Tagore, Bankim Chandra Chattopadhyay, Sarat Chandra Chattopadhyay, Michael Madhusudana Dutta, Dwijendralal Ray, Kazi Nazrul Islam, Sarat Chandra Chattopadhyay, Bibhutibhusan Bandyopadhyay, Satyajit Roy, Jagadish Chandra Bose etc. and the social reformers like Raja Rammohan Ray, Henry Louis Vivian Derozio, Keshub Chandra Sen, Swami Vivekananda, RamkrishnaParamhangsa Dev, Sri Aurobinda etc., the name of Ishwar Chandra is written in golden letters. $\mathrm{He}$ has a personality made with extreme dedication to his education and latter in profession, vast knowledge in eastern and western disciplines, devotion to his parents, morality, mercifulness, kindness, sympathy, co-operation, nonconservative attitude, a heart full with regret to the then situation of women and a vision to give Indian educational system a modern perspective. He is very known for his educational and social activities throughout the world. He paved the way for introducing the modern education system in India. He is also known for his literary work. He is the pioneer of the present form of Bengali literature. As he was a Sanskrit scholar, he has deep understanding in this discipline which made him understand the underlying problems of Bengali literature. He also took major initiatives for the education of women, which was then ignored by the higher authorities of India. He banned polygamy, child marriage and has done legal activities for starting widow remarriage. His linguistic, educational and social activities which he has done from his early life till his death is cordially memorable to the Indians, especially to the Bengalis from that time to the present day.

\section{A. Early life and Education}

The key figure of the Bengali Renaissance, Ishwar Chandra Bandyopadhyay was born on $26^{\text {th }}$ September 1820 (on $12^{\text {th }}$ Ashwin 1227 according to Bengali lunar calendar) in a poor 
Kulin Brahmin family in the village Birsingha, under the sub-division of Ghatal of Midnapore district. Then the village was in the Hooghly district. The name of his father was Thakur Das Bandyopadhyay and mother Bhagwati Devi. He was their elder son. His father was a clerk in a shop of Kolkata. His mother was very kind hearted, open minded and honest woman. She was "Dynamo" to him and was very obedient to her. She was the first trainer and teacher of Ishwar Chandra. He had married to Dinamani Devi and had their only son Narayana Chandra Bandyopadhyay. He spent his childhood with extreme poverty, but he continued his journey with full determination and perseverance. He got his primary education at the age of five in his village Pathshala of Kalikanta Chattopadhyay. Here, he studied three years up to the age of eight and got knowledge of language, grammar, mathematics and many other disciplines. In November 1828 his father brought him to Kolkata and admitted him to a Pathshala. For three months he studied there and being attacked by a serious disease. After the recovery of his disease, he was admitted to the Sanskrit College on $1^{\text {st }}$ June 1829. There he acquired the knowledge of Grammar from 1829 to 1833 , Literature on 1833-1835, Rhetoric on 18351836, Vedanta on 1836-1838 and Smriti on 1838-1839. Later, in April 1839 he studied Hindu Law and English and passed the examination of Hindu Law committee with excellence. At the end of 1839 he entered to study Nyaya Shastra for two years up to 1841 . He had the knowledge of Logic and Astronomy. After the completion of all his long study of 12 years and 6 months in the Sanskrit college he was honored with the title of "Vidyasagar" by all the pandits of Sanskrit college on $4^{\text {th }}$ December 1841. The meaning of "Vidyasagar" is the "Ocean of Knowledge". Soon after his education life he started his professional teaching career. (B. Ghosh.)

\section{B. Work and Professional Life}

In a few days of getting certificate from Sanskrit college, Vidyasagar appointed as the head pandit of Fort William College in the Department of Bengali, on $29^{\text {th }}$ December 1841. He was then only 21 years old. The secretary of this college John Marshal was very impressed with the vast knowledge of Vidyasagar. Here, he taught five years up to the year 1846. But as a Sanskrit pandit he was eagerly looking for a job in Sanskrit college. Then on $6^{\text {th }}$ April 1846 he joined Sanskrit college in the post of Assistant Secretary. After joining in the Sanskrit college, he framed a curriculum design and wanted to reform the education system. For this purpose, he made a report which was very much praised by John Marshal. Not only him, Vidyasagar's educational thoughts made a stir among the administrative authorities. But the then conservative college secretary Rasamoy Dutta opposed his idea and criticized his report. For being faced obstacles from college authority he became very upset and resigned the post of assistant secretary of Sanskrit college. He was the only the age of 26. After resigning the post, he had no job. So, he bought a Sanskrit press machine namely "Sanskrit Jantra" and a bookstall namely "Sanskrit Press
Depository". He did the job of writer, publisher and bookseller parallelly. After being jobless for a long time, he got the job of head writer and treasurer in the Fort William College on $1^{\text {st }}$ March 1849 in a salary of 50 Rs. /month. On $5^{\text {th }}$ December 1850 he appointed as the Professor of Literature in Sanskrit College. Then the secretary Rasamay Dutta resigned soon. On $22^{\text {nd }}$ January 1851 he became the Principal of Sanskrit College. He held the post of Principal up to $5^{\text {th }}$ August 1858. Besides the post of Principal, he has given the responsibility of the assistant inspector on May, 1855 and he fulfilled his responsibility with proficiency. In his professional life he has done many educational and social reformations for the people of India especially Bengal, which are discussed below.

\section{Educational Activities}

Ishwar Chandra's Philosophy of Education was based on humanity. He deeply observed the problems and weakness in the then education system. He knew to change the fate of crore of Indians, education is the only weapon. As that time, he studied in the Sanskrit college he closely observed the situation of Indian Education System. So, he dedicated himself for the reconstruction of education system. As a principal, he opened the door of Sanskrit college for all. Till then it was the institution only for the Brahmins and Vaidyas, who has the right to study Veda and Sanskrit. Not only that, he radically changed the syllabus of Sanskrit college, fixed nominal fees and weekly holiday. He knew, for the expansion of education among mother tongue is the only medium. So, instead of teaching Grammar and Mathematics through Sanskrit, he began to use English and Bengali as the medium. He introduced western languages and subject matter in Indian education. He was the first who gave importance on the western science and philosophy besides eastern shastras. He established 20 model schools and many girls' schools for the expansion of girls' education. He also established a normal school for making competent teachers for these schools. He opened thirty-five girls' schools between 1857 and 1858. One of his major contributions was establishment of Calcutta Metropolitan Institution for higher education. Now it is called "Vidyasagar College". He also was directly involved in the establishment of "Calcutta Female School" by the help of Drinkwater Bethune in 1849. Now it is called "Bethune School". He has also made his valuable contribution in education through his writings. He wrote many text books, translated books, bio-graphical books and was a continuous writer of different magazines.

\section{Social Activities}

Ishwar Chandra has made his valuable contribution not only in the educational field but also, he spread his wisdom, love and sympathy among all the poor, downtrodden, sick and ignored people. He was very upset to see that the superstitions and darkness of Hindu culture has kept them blind to all situations. He has got pain to see the then situation of women. Besides the establishment of girls' 
schools, he tried with all his effort for enacting widow remarriage. He explained widow remarriage with taking examples from Indian shastras and finally on $26^{\text {th }}$ July 1856 he legally passed widow remarriage act namely Hindu Widow Remarriage Act 1856. Not only that, to stop polygamy among the Kulin Brahmins and child marriage the Civil Marriage Act was passed in 1872. It was not a easy task to understand the orthodox Hindu authorities to accept this change. For this he has written many books and articles in the magazines to create a large amount of people's support in favor of him. He always served others from his own paid salary. In many aspects he did not get any support not from the government nor from the others, but he continued his journey and reached his ultimate aim. His contribution in the upliftment of the women by eradicating blind superstitions and tortures in the name of rituals will be always in the heart of the women.

\section{OBJECTIVES OF THE STUDY}

The objectives of the study are, to:

1. Find out the literary works of Ishwar Chandra Vidyasagar in the period of $19^{\text {th }}$ century.

2. Find out the activities of Ishwar Chandra Vidyasagar for the development of Bengali language among the children.

3. Analyze the present relevancy of his linguistic activities in the light of education, philosophy and psychology.

\section{SIGNIFICANCE OF THE STUDY}

This study has the following significance described by the researcher. These are:

1. Through the findings of the research, the citizens of India and West Bengal will know the origin of Modern Bengali language.

2. They will be able to know the contribution of Ishwar Chandra Vidyasagar and his colleagues to the development of Bengali literature and language.

3. The Philosophical and Psychological principles that are deep rooted in the ideas and thinking of Vidyasagar will enable us to know the strong base that the Bengalis have.

4. And finally, the findings of this study may retrieve back the lost importance and position of Bengali literature and language among the Indians.

\section{RESEARCH QUESTIONS OF THE STUDY}

This study has the underlying research questions which are framed by the researcher according to the framed objectives. The research questions are:

1. What are the literary works of Ishwar Chandra Vidyasagar during the period of $19^{\text {th }}$ century?

2. What activities he has done for the development of language among the children?
3. How he has made Bengali a modern Indian language for the expansion of education and eradication of superstations among the mass?

4. How much his linguistic and literary works support the principles of EducationalPhilosophy and Educational Psychology in present day?

\section{METHODOLOGY}

The study is a Descriptive type, historical research study. So, a format of Historical research study is followed by the researcher to carry on the study and in presenting research report.

\section{A. Data Source}

The sources for data collection used by the researcher are basically secondary in nature, but primary data sources are also used for this purpose.

\section{B. Data Analysis}

For the analysis of collected data documentary analysis method was applied by the researcher to find answers of above stated research questions.

\section{DATA ANALYSIS AND INTERPRETATION}

\section{A. Literary Works of Ishwar Chandra}

Ishwar Chandra, besides his professional and social work activities, has dedicated much of his time on the writings of text books, reformist literatures, translated books and in the work of publication of these books. He not only has involved himself in writings but he also made his colleagues and friends inspired to write Bengali books and literatures. Some of them are Akshay Kumar Datta, Giris Chandra Vidyaratna, Jogendra Nath Bandyopadhyay, Madan Mohan Tarkalankar etc. His contribution in the field of Bengali literature is praiseworthy. We all know the world-famous writer and dramatist Rabindranath Tagore, whose writings has created an honorable position in the world of literature. After Rabindranath Tagore, the name came Ishwar Chandra. His has written to fulfill some of his aims by his writings. It may be to encourage young generation or to eradicate social evils, or may be to fulfill the crisis of good Bengali literatures. On that time, as the medium of education was Sanskrit, there was very crisis of Bengali books for the public to read. Vidyasagar by his own initiatives wrote many books. In 1847, at his very young age he wrote "VetalaPanchavingsati". It was a translated book from the Sanskrit book "Kathasaritsagara". It consists 25 tales of Betaal and the king Bikramaditya. It is one of the famous works of Vidyasagar. (A.P) Not only he wrote books, but he admired all the great poets and writers and published their books in his own hand. One of them was the great poet Bharat Chandra. Later in 1848, Vidyasagar wrote "BanglarItihas", from John Marshal's writing "History of Bengal". In 1849, he started writing in the Bengali periodical namely "SarbaShuvankari", 
"TattwabodhiniPatrika", "Somprakash" etc. His able writings very rapidly made the magazine successful. In September, 1850 Vidyasagar's one more creation appeared to the Bengalis i.e. "Jibana-Charita". This was also a translated book of Chamber's 'Biography", which contained the life history of many western scientists. In 1854 he wrote "Shakuntala" and in 1860 he wrote "Sitar Banabas". Even he translated Shakespeare's "The Comedy of Errors" and rewrite it in Bengali with an easy and narrative mode in 1886. The name of his book was "Bhrantibilas". His first article in favor of widow remarriage was published in "Bengal Spectator" in 1842. His others literary works include "Mahabharata" in 1860, "OtiAlpaHoilo" in 1873, "AabaarOtiAlpaHoilo" in 1873, "Brajavilaas" in 1884, "Ratnopariksha" in 1886. Apart from the above literature books, he has also written many controversial books on the social reforms. Among them the most notable writings are, "Bidhobabibaha" in 1855 part 1 and part 2, "Bahubibaha" part 1 in 1871 and part 2 in 1873 and "Balyabibaha". He has also written many text books for the children. Among them the most honorable creation of Vidyasagar is the famous "Barnaporichoy". He wrote this book in 1851. Others like "Badhoday" in 1851, "Kathamala" in 1856, "Charitabali" in 1856, "SamaskritaByakaranerUpokromonika" in 1851, "ByakaronKoumudi" in 1853-1863 and "Rijupath" part 1,2 and 3between 1851 to 1852 .

\section{Development of Modern Bengali Language}

The development of modern Bengali language began from the $19^{\text {th }}$ century with the contribution of the Bengali Pandits of Fort William College. Their translated works, text books publication, publication of magazines and periodicals started to give the platform for the evolution of Bengali language and literature. Before, this era Bengali language and literature appeared to the Bengalis most difficult to read as it consists the ancient Bengali language Sanskrit. Then Sanskrit was the only medium of education. After Ishwar Chandra Vidyasagar the era of modern Bengali language started. It can be said, he is pioneer of the modern Bengali language. As he translated many books from their original version to Bengali, it appeared to the Bengalis very easy to understand. He translated Sanskrit, Hindi and English books mainly for the aim of mass education. Ishwar Chandra was a Sanskrit scholar and he has made significant contribution in simplifying and modernizing Bengali prose. His pioneering work which he has done in 1851 by his publication of famous "BarnaPorichay". It is the book for Bengali alphabets. "Barna" means Letter or Alphabet and "Porichay" means Introduction. In this book Vidyasagar reconstructed and reformed Bengali letters into twelve vowels and forty consonants.It is a classic in Bengali Literature. One's education life starts with this model book. Vidyasagar used very plain, easy and elegant words in all his writings that made the readers very pleasant. His efficiency and grip of Bengali language can be seen in his writings of "BetaalPanchvinsati" and "BanglarItihas". In translating books, he did not just change their language rather made them more suitable to the readers by eliminating the vulgarity of the original books. Before him, there was no Bengali or Sanskrit Grammar book for the readers. Vidyasagar was the first who wrote a book of Sanskrit Grammar and the Bengali Grammar namely, "ByakaronKoumudi". It was his another monumental work on Grammar. Although he wrote many biographical books for the young children. He maintained his writing style in these books also. Vidyasagar made his contribution in Bengali prose also. Before him there was lack of vocabulary, beauty, smoothness and lucidity. Ishwar Chandra was the first who took initiatives and modified the sentence structure of Bengali prose, discovered collocation, established correlation between subject, verb and object. Not only that, he made the reader to stop in proper punctuation marks, by discovering the relation between breath-pause and meaning-pause. Which was previously not known to the writers. Only Akshay Kumar Datta used the English punctuation marks in Bengali. Vidyasagar did not have any single style of writing, rather his style varied according to his various writings. Thus, he has created Modern Bengali Language and made his contribution on Modern Bengali Literature. (Murshid, G. 2018)

\section{Relevance of Vidyasagar's Linguistic and Literary works in Present Context}

One of the significant contributors of modern Bengali literature in its early developmental stage of nineteenth century was Ishwar Chandra Vidyasagar. He is considered "The Father of Modern Bengali Prose". He was an educational reformist also. His philosophy of education was very much influenced by the western theory of philosophies. He has a deep knowledge of Indian philosophy also. When he was the Principal of Sanskrit college, he modified the educational system, curriculum and others administrative rules of the college. His educational plan can be considered as the first Indian Educational Plan. He rejected Halliday's proposal of "Downward Filtration Theory" and has given stress on the mass education by one's own mother language. He was the only man who understood the problem of Indian people and thus tried with his all effort throughout his life to make them educated. There is no question that we all are blessed with his educational and social activities. The modern Indian society and Bengali literature is the contribution of one and only the great person Ishwar Chandra Vidyasagar. The preset relevance of his linguistic and literary work is discussed below:

\section{Principles of Educational Philosophy}

Vidyasagar's philosophy was not based on the principles of spirituality. Rather he believed in the practical application of these philosophical principles in the lives of the students or people. He was influenced by the Indian Vedanta and Sankha philosophy. Many western philosophical thoughts and the educational ideas of western philosophers influenced him. Western philosophies like, Idealism, Pragmatism and Realism- these three philosophical ideas are combinedly seen in Vidyasagar's philosophy of 
Education. Very well-known western philosophers like, John Mill, John Dewey, Johann Herbert, John Locke had great impact on Vidyasagar's thought. But he never blindly accepted these ideas at all. (Banu, A. and Alam, S. 2016)

i. To make readers understand about the difference between the eastern and western philosophy, he included western philosophy along with eastern in the curriculum of Sanskrit college. Which we may see as the subject content in the present curriculum till now.

ii. Like Herbert, Vidyasagar, always gave importance in the moral development of the students. This is one of the major educational aim of Idealism. For the moral development of students, he always added moral talks at the end of every short story in the books of "Kathamala", "Bodhodoy" etc.

iii. He also had the philosophy of Humanism. Which we can see in his love for the human beings. For the proper development of the individual he has not only written books but also made them easy to understand for the countrymen. It is not only expressed his humanistic outlook but also a utilitarian and pragmatist outlook.

iv. Vidyasagar always wrote book by considering its practical application and utility, it may be his writing of the book "Bidhobabibaha", "Bohubibaha" or Others translated books like "Jibanacharita". It was the reflection of his realistic and pragmatist philosophical beliefs.

v. He was influenced by the educational philosophy of John Mill, John Locke and John Dewey, who believed students should be learn from simple to complex. Following this rule of learning Vidyasagar set up the content of his text books for students. Like in "BarnaPorichay" part 1 he arranged the Bengali alphabets for continuously learning pronunciation and classification of letters and in part 2 he mentioned some sentences with moral advices.

vi. Vidyasagar's realistic philosophy again can be seen in his writings on "Bodhodaya". Where he introduced children with the naturalistic world and the world with simple noble virtues.

vii. Vidyasagar again added for the young reader in "Bodhodaya", the concept of the supreme power or the Creator of the universe as the "NirakarChaitanyasvarup" (Consciousness in purity without form). This Vedantic philosophical view he conveyed to the young boys through his literary work.

\section{Principles of Educational Psychology}

Ishwar Chandra Vidyasagar in his literary creation and language developmental activities not only follow the principles of different eastern and western philosophical thoughts, but many psychological principles he followed in structuring and organizing the subject materials and books for the readers. These are: i. Vidyasagar implemented in his text books the principle of simple to complex. In "Barnaporichay" he systematically arranged sounds, simple alphabets, monosyllabic words, disyllabic words and then simple sentences. The rule of simple to complex he always followed in his others text books writings.

ii. According to the Constructivist Approach, the presentation of subject matter is very important for proper learning. Vidyasagar did not use a single style for the presentation of subject content in his books. He used different writing style.

iii. The third psychological principle that Vidyasagar had in his writing is the principle of interest and active learning in education. He organized the text books for very young beginners with very interesting pictures and innovative concepts. So that students will attract and have interest to read them.

iv. The developmental principles of psychology have also seen through his literature creation and presentations. The theory of Moral development by Kohlberg as we see the gradual development of morality among students. Vidyasagar not through his writings but also through the gradual presentation of these books identified moral development occurs in children step by step. Vidyasagar's concept of moral development are shown below step by step:

In First part of "BarnaPorichay" students acquired the knowledge of letters, rhythmic words and small sentences. In the second part of "BarnaPorichay" students gradually came across the two famous moral stories of "Rakhal" the bad boy and "Gopal" the good boy. (Good Boy-Nice girl orientation stage of Kohlberg).

For the second-grade students he suggested "Kathamala", it is the book mostly animal stories with moral. Based on Aesop's fables.

For third grade students he wrote "Charitavali". From here students will learn about the life stories (Biographies) of some great persons'

At the fourth grade he suggested to read "Bodhodaya", consists the description of natural objects and phenomenon of everyday experiences.

Finally, "Akkhyan-manjari" a book contains seventy-eight true stories, episodes from the lives and travel experiences of different countries.

\section{MAJOR FINDINGS}

The results or findings of the study are stated below:

1. Ishwar Chandra Vidyasagar's literary works which are discussed above is not possible to explain in one sentence. $\mathrm{He}$ is the one of the greatest writers of Bengali literature'. His milestone work "BarnaPorichay" will remain as the beginner book to the readers after many centuries. 
2. His contribution in the development of modern Bengali language and literature can not be ever excelled. Even, standing in the twenty-first century every Indian and Bengali appreciate him and his creation with proud.

3. He simplified Bengali literature for the understanding of young children and the mass people of India. He used some books for the eradications of social evils and reformations of Indian Education. The name of such books are: Bahubibaha, BidhabaBibaha etc

4. And lastly, to find the answer of the third question the researcher found that his pre-independent educational plan paved the way of successful post-independent educational plan. Till now, not all but his educational ideas are being reflect in the present educational plan, curriculum, teaching-learning process and in others institutional activities.

\section{CONCLUSION}

About Ishwar Chandra, Rabindranath Tagore wrote, "One wonders of God, in the process of producing forty million Bengalis, produced a man". (Wikipedia). He was a man with iron will power. His educational thoughts realized the then British administrative authorities that Indians have the power and ability to make their own educational plan and can make run this plan also. He was the first who has understood that only education through mother tongue can make people educated. He had a Bengali heart with combined knowledge of eastern and western education. He has made unforgettable contribution in the social reformation, educational reformation and development of Bengali literature. He spent his last 18-20 years among 'Santhals' at "Nandan Kanan" in Jharkhand and has left the world in $29^{\text {th }} \mathrm{July}, 1891$. Many sculptures were made in his memory and respect, like "Vidyasagar Setu" over Hooghly river, organization of "Vidyasagar Mela" in Kolkata and Birsingha, establishment of "Vidyasagar University" in Pashim Midnapore, "Vidyasagar College" in Kolkata, "Vidyasagar Street" in central Kolkata, "Vidyasagar Stadium" at Barasat, and "Vidyasagar Residence Hall" at Kharagpur.

\section{REFERENCES}

[1] Vidyaratna, S. C. Vidyasagar Jibancharit, Bengali 1321, Siddheswar Press Depository, College Street, Kolkata. Retrieved fromhttps://commons.m.wikimedia.org

[2] Vidyasagar, I. C. Barnaporichay Part 1, 1932, Sanskrit College, Kolkata. Retrieved fromhttps://commons.m.wikimedia.org

[3] Vidyasagar, I. C. Jibancharit, 1857, The Sanskrit Press, Kolkata. Retrieved fromhttps://commons.m.wikimedia.org

[4] Vidyasagar, I. C. Kathamala, 1941, Sanskrit College, Kolkata. Retrieved fromhttps://commons.m.wikimedia.org

[5] Vidyasagar, I. C. Shakuntala, 1911, Sanskrit College, Kolkata. Retrieved fromhttps://commons.m.wikimedia.org

[6] Banu, Dr. A. and Alam, Mr. S. (March, 2017). Similarities and dissimilarities between Ishwar Chandra Vidyasagar and Rabindranath Tagore's philosophy of education. International Journal of Education and Psychological Research, 6(1), 66-73. Retrieved fromwww.ijepr.org

[7] Banu, Dr. Aand Alam, Mr. S. (June, 2016). Influence of western knowledge and cultures upon Ishwar Chandra Vidyasagar and his philosophy of education. International Journal of Education and Psychological Research, 5(2), 12-18. Retrieved fromwww.ijepr.org

[8] Chatterjee, A. (15 ${ }^{\text {th }}$ July, 2007). Ishwar Chandra Vidyasagar: A Profile of the Philanthropist Protagonist. Retrieved fromwww.bolokids.com

[9] Devnath, S. (5 ${ }^{\text {th }}$ May, 2014). TattabodhiniPatrika. Retrieved on www.en.banglapedia.org

[10] Ghosh, B. Vidyasagar O BangaliSamaj, 1984, Orient Longman, Kolkata-72

[11] Haldar, G. (1972). Vidyasagar A Reassessment. West Bengal Public Library Network. Retrieved from www.dspace.wbpublibnet.gov.in

[12] Ishwar Chandra Vidyasagar. Retrieved on https://en.m.wikipedia.org

[13] Kumar, Dr. R. (19 $9^{\text {th }}$ July, 2017). Ishwar Chandra Vidyasagar: Women education and Empowerment. Social and Women. Retrieved fromwww.businesseconomics.in

[14] Kumar, S. (April-June, 2016). Contribution of Socio-Religious Reform Movement to attain the social justice in Indian society. International Journal of Advances in Social Sciences, 4(2), 107-110. Retrieved fromwww.anvpublication.org

[15] Kundu, M. (27 $7^{\text {th }}$ September, 2012). Ishwar Chandra Vidyasagar: Ocean of knowledge who famous around India, Sind river of kindness, True friend of poor people. Retrieved from www.manashsubhaditya.blogspot.com

[16] Luca, R. (19 March, 2018). Ishwar Chandra Vidyasagar Biography, Social Reforms and Quotes. Retrieved fromhttps://biographypoint.com

[17] Mitra, S.C. (2016). Isvar Chandra Vidyasagar, a story of his life and work/Introduction. Retrieved on https://en.m.wikisource.org

[18] Modern Bengali Literature. Retrieved on www.gktoday.in

[19] Murshid, G. (25 $5^{\text {th }}$ March, 2018). Vidyasagar, Ishwar Chandra. Retrieved on www.en.banglapedia.org 